\title{
Electrodeposition of Aluminium-Vanadium Alloys from Chloroaluminate Based Molten Salt Containing Vanadium Ions
}

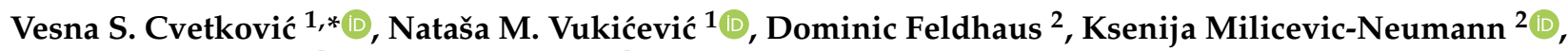 \\ Tanja S. Barudžija ${ }^{3}\left(\mathbb{D}\right.$, Bernd Friedrich ${ }^{2}$ and Jovan N. Jovićević $^{1}$ \\ 1 Department of Electrochemistry, Institute of Chemistry, Technology and Metallurgy, National Institute, \\ University of Belgrade, Njegoševa 12, 11000 Belgrade, Serbia; vukicevic@ihtm.bg.ac.rs (N.M.V.); \\ jovicevic@ihtm.bg.ac.rs (J.N.J.) \\ 2 IME Process Metallurgy and Metal Recycling, Institute of RWTH Aachen University, Intzestrasse 3, \\ 52056 Aachen, Germany; DFeldhaus@ime-aachen.de (D.F.); kmilicevic@ime-aachen.de (K.M.-N.); \\ bfriedrich@ime-aachen.de (B.F.) \\ 3 Institute for Nuclear Sciences Vinča, University of Belgrade, P.O. Box 522, 11001 Belgrade, Serbia; \\ tbarudzija@vin.bg.ac.rs \\ * Correspondence: v.cvetkovic@ihtm.bg.ac.rs; Tel.: +381-11-3640-228
}

\section{check for}

updates

Citation: Cvetković, V.S.; Vukićević, N.M.; Feldhaus, D.; Milicevic-Neumann, K.;

Barudžija, T.S.; Friedrich, B.; Jovićević, J.N. Electrodeposition of Aluminium-Vanadium Alloys from Chloroaluminate Based Molten Salt Containing Vanadium Ions. Metals 2021, 11, 123. https://doi.org/ 10.3390/met11010123

Received: 18 December 2020 Accepted: 7 January 2021 Published: 10 January 2021

Publisher's Note: MDPI stays neutral with regard to jurisdictional clai$\mathrm{ms}$ in published maps and institutional affiliations.

Copyright: (C) 2021 by the authors. Licensee MDPI, Basel, Switzerland. This article is an open access article distributed under the terms and conditions of the Creative Commons Attribution (CC BY) license (https:// creativecommons.org/licenses/by/ $4.0 /)$.

\begin{abstract}
The Al-V alloys were synthetized by potentiostatic electrodeposition onto a glassy carbon electrode from equimolar $\mathrm{AlCl}_{3}+\mathrm{NaCl}$ bath containing vanadium ions at $200{ }^{\circ} \mathrm{C}$. The alloy deposits were characterized by $\mathrm{X}$-ray diffraction, scanning electron microscopy, and energy dispersive spectroscopy. The deposits were identified as $\mathrm{Al}_{3} \mathrm{~V}$ and $\mathrm{AlV}_{3}$ alloys. It was found that intermetallic alloys were synthetized during aluminium underpotential deposition onto vanadium metal that was previously deposited on the glassy carbon electrode by diffusion-controlled overpotential deposition. Alloys were the result of solid-state interdiffusion between the initially deposited vanadium and the subsequently deposited aluminium. As a source to secure a constant concentration of vanadium in the electrolyte during deposition, vanadium anodic dissolution, and $\mathrm{VCl}_{3}$ melt addition were studied. The effect of vanadium ion concentration in the electrolyte on the composition and the surface morphology of the obtained deposits was investigated. The results indicate that controlled vanadium and aluminium codeposition could be a further step to the successful development of an advanced technology for $\mathrm{Al}_{3} \mathrm{~V}$ and $\mathrm{AlV}_{3}$ alloy synthesis.
\end{abstract}

Keywords: Aluminium-Vanadium alloys; $\mathrm{AlCl}_{3}+\mathrm{NaCl}$ equimolar molten salt; electrodeposition; anodic dissolution; $\mathrm{VCl}_{3}$

\section{Introduction}

Trialuminides $\left(\mathrm{Al}_{3} \mathrm{X}\right)$ are alloys where $\mathrm{X}$ represents a transition metal, such as titanium, zirconium, iron, vanadium, niobium. They are found to be very promising materials in many areas of advanced technologies, particularly in aerospace industry [1-5]. Compared to Ni-based alloys that are extensively used in aircraft structures, trialuminides have $20-50 \%$ lower density. Combined with high strength and improved thermal stability, trialuminides offer a potential light-weight alternative $[3,6]$. Within the group of trialuminide intermetallics, vanadium trialuminide $\left(\mathrm{Al}_{3} \mathrm{~V}\right)$ exhibits a high melting temperature $\left(1360{ }^{\circ} \mathrm{C}\right)$, low density $\left(3.34-3.68 \mathrm{~g} \cdot \mathrm{cm}^{-3}\right)$ and excellent oxidation resistance which is presently of particular interest for high-temperature structural material applications [3,6]. However, Okamoto at al. indicates a segregation temperature of $1249{ }^{\circ} \mathrm{C}$ for the $\mathrm{Al}_{3} \mathrm{~V}$ phase [7]. The solid-state diffusion of vanadium into aluminium is very slow and rarely exceeds more than about $1 \%$ atomic fraction [8,9]. Even at those levels, its presence in aluminium increases the tensile strength at room as well as elevated temperatures [6]. Al-V alloys are playing an essential role as a source of aluminium and vanadium for $\alpha+\beta$-titanium alloys, like Ti-6Al-4V or metastable $\beta$-titanium alloys like Ti-15V-3Cr-3Al-3Sn $[2,10]$. 
Efforts were made to synthesize the $\mathrm{AlV}_{3}$ intermetallic, interesting because of its potential as a super-conducting material. An $\mathrm{AlV}_{3}$ alloy with hexagonal structure and lattice parameters $\mathrm{a}=0.7070$ and $\mathrm{c}=0.9565 \mathrm{~nm}$ was synthetized by annealing the mixture of two powders ( $\mathrm{Al}$ and $\mathrm{V}$ ) in the stoichiometric ratio 3:1 at temperature above $1500{ }^{\circ} \mathrm{C}$ and high pressure of $30 \mathrm{kbar}$ [11]. Tetragonal $\mathrm{AlV}_{3}$ with a lattice parameters $\mathrm{a}=0.6167$ and $\mathrm{c}=0.9481$, was obtained at lower temperature $\mathrm{T} \leq 1300^{\circ} \mathrm{C}$ and pressure [11]. Others have produced $\mathrm{AlV}_{3}$ by annealing at $100{ }^{\circ} \mathrm{C}$ in a quartz tube, but attempts to duplicate the results were unsuccessful [12]. At the end the authors came to the conclusion that annealing in the quartz tubes causes contamination by $\mathrm{Si}$, and that only the bcc $\mathrm{AlV}_{3}$ phase is stable in the binary system [12].

Currently, methods used in the production of Al-V alloys are mechanical alloying process, aluminothermic reduction process, and rapid solidification. In the search for desirable material attributes more attention has been focused on the development of new, innovative, and unconventional manufacturing methods [1,2,6,13,14]. Electrochemical deposition provides a very suitable way for a controlled production of pure metals or alloys. By adjusting electrolysis parameters such as electrolyte composition, temperature of electrolysis, deposition potential, deposition current density, electrodeposition time, and type of working substrate, varying structure types and contents can be achieved.

Various molten salt electrolytes have been tested and proposed for Al-V alloy electrodeposition, including inorganic (halide [10,15-18] and chloroaluminate $[8,9,19]$ ) and organic (ionic liquids [20]) electrolytes. Recently, several studies were reported on the deposition of Al-V alloys from inorganic molten salts, mostly from halide-based electrolytes $[10,16]$. Meanwhile, electrodeposition of Al-V from chloroaluminates has been rarely investigated $[8,9,19]$. A number of publication devoted to the electrochemistry of vanadium species in halide melts showed that the valence of vanadium species in halide electrolytes depends greatly on the experimental conditions, such as the electrolyte temperature and the source of the vanadium ions being introduced into the electrolyte $[10,15-17]$.

Attempts to electrodeposit Al- $\mathrm{V}$ alloys from chloroaluminate molten salt $\mathrm{AlCl}_{3}+\mathrm{NaCl}$ $+\mathrm{KCl}$ electrolyte containing different vanadium oxides $\left(\mathrm{K}_{2} \mathrm{VO}_{2} \mathrm{~F}_{3}\right.$ or $\left.\mathrm{V}_{2} \mathrm{O}_{5}\right)$ by controlled current density have been reported by Verdieck and Yntema [19]. The resulting deposit did not contain appreciable amounts of vanadium. Meanwhile, Jovićević et al. presented a study on Al-V alloy formation as a result of aluminium electrodeposition from equimolar chloroaluminate $\mathrm{AlCl}_{3}+\mathrm{NaCl}$ melts onto a vanadium substrate. The authors reported findings of three $\mathrm{Al}-\mathrm{V}$ intermetallics, including $\mathrm{AlV}_{3}$ (also referred to as A15 compound), being synthesized by aluminium underpotential deposition (UPD) onto a vanadium cathode [8].

The present study aims to be a next step towards developing a controllable process for the synthesis of prospective materials such as $\mathrm{Al}_{3} \mathrm{~V}, \mathrm{AlV}_{3}$, and other intermetallics. A further objective of the ongoing research is to develop an easier way to form Al-V alloys by electrochemical codeposition of the constituents present in the electrolyte.

\section{Materials and Methods}

For all experiments, the basic electrolyte was made of an equimolar mixture of 0.19 mol $\mathrm{AlCl}_{3}$ (>99\%, Sigma-Aldrich, St. Louis, MO, USA) and $0.19 \mathrm{~mol} \mathrm{NaCl}$ (p.a., SigmaAldrich, St. Louis, MO, USA). The preparation of this electrolyte was described in detail in previous works $[8,21,22]$.

Two different procedures were used to prepare the vanadium containing molten salt electrolyte: (1) a controlled anodic dissolution of vanadium metal in the equimolar melt, or (2) an addition of $\mathrm{VCl}_{3}(>97 \%$, Acros Organics, Geel, Belgium) to the equimolar basic salt mixture prior to melting. All experimental and preparation procedures were performed in a glove box under an argon atmosphere to minimize contamination or moisture absorption. The electrochemical experiments were performed by Potentiostat/Galvanostat Model 263A, (Princeton Applied Research, Oak Ridge, TN, USA) and accompanying software (Princeton Applied Research, Oak Ridge, TN, USA). For the investigation of the vanadium anodic dissolution in the equimolar melt, the electrochemical cell set up was: vanadium (99.99\%, 
Sigma-Aldrich, St. Louis, MO, USA) as a working (WE) and counter electrode (CE), and Al rod (3mm diameter, 99.999\%, Alfa Aesar, Haverhill, MA, USA) as a reference electrode. The surface area of the working and counter electrodes that was in contact with the electrolyte was $4 \mathrm{~cm}^{2}$. Determination of a suitable dissolution potential for the metal vanadium was done by recording potentiodynamic polarization curves and cyclic voltammograms (CV) of the vanadium WE in the equimolar melt at $200{ }^{\circ} \mathrm{C}$. Voltammograms with different scan rates were recorded from starting potential, $\mathrm{E}_{\mathrm{I}}$, slightly more positive to the vanadium open circuit potential ( $\mathrm{OCP} \approx 1.130 \mathrm{~V}$ measured relative to the aluminium reference electrode) to:

(1) Anodic end potential, $\mathrm{E}_{\mathrm{AF}}$, and back to $\mathrm{E}_{\mathrm{I}}$, or

(2) To different anodic end potential, $\mathrm{E}_{\mathrm{AF}}$, then toward different cathodic end potential, $\mathrm{E}_{\mathrm{CF}}$, and back to the starting potential, $\mathrm{E}_{\mathrm{I}}$.

Controlled dissolution of the $\mathrm{V}$ metal in the basic equimolar melt was carried out by applying a constant anodic overpotential at $200{ }^{\circ} \mathrm{C}$ selected on the basis of the obtained results.

For the electrochemical experiments involving aluminium and vanadium electrodeposition, a three-electrode cell, consisting of a glassy carbon working electrode, GC (99.99\%, HTW SIGRADUR®G, Thierhaupten, Germany), a vanadium counter electrode, and an aluminium reference electrode (RE), was used. The GC working electrode was polished with $0.05 \mu \mathrm{m}$ alumina powder (Merck) and cleaned by sonication in ethanol and Milli-Q water in several $3 \mathrm{~min}$. intervals. The aluminium electrode RE, was etched in solutions made of $50 \mathrm{vol} \% \mathrm{HF}+15 \mathrm{vol} \% \mathrm{H}_{2} \mathrm{O}$ and conc. $\mathrm{NH}_{4} \mathrm{OH}+5 \mathrm{vol} \% \mathrm{H}_{2} \mathrm{O}_{2}$ and cleaned with deionized water and absolute ethyl alcohol. Vanadium electrodes were etched in the solution made of $1: 1=65 \% \mathrm{HNO}_{3}: \mathrm{H}_{2} \mathrm{O}$ and cleaned with deionized water.

Cyclic voltammograms on the GC working electrode in equimolar $\mathrm{AlCl}_{3}+\mathrm{NaCl}$ electrolyte with vanadium ions added by controlled anodic dissolution of $\mathrm{V}$ metal or by $\mathrm{VCl}_{3}$ addition, started from potential $\mathrm{E}_{\mathrm{I}}$, usually $0.050-0.100 \mathrm{~V}$ more negative than the GC open circuit potential (measured against the aluminium reference electrode), to the cathodic potential limit, $\mathrm{E}_{\mathrm{CF}}$, and returned to the initial potential, $\mathrm{E}_{\mathrm{I}}$, using varied scan rates. $\mathrm{CV}$ were performed within the same potential range, with the scan interrupted at a chosen cathodic end potential, $\mathrm{E}_{\mathrm{CF}}$. The potential was held there at varying intervals, before starting the return scan.

Potentiostatic deposition of vanadium and aluminium on the GC electrode at $200{ }^{\circ} \mathrm{C}$ was performed from the equimolar melts containing vanadium ions from both sources. In the electrolyte with vanadium ions added by anodic dissolution, electrodeposition was done at $0.020 \mathrm{~V}$ vs. Al. In the electrolyte with $\mathrm{V}$ ions added in the form of $\mathrm{VCl}_{3}$, electrodeposition was done at $0.050 \mathrm{~V}$ vs. Al. The deposition process started 5 min after insertion of the working electrode into the electrolyte in order to allow the system to achieve thermal equilibrium.

After potentiostatic deposition, the GC electrode was taken out of the cell, washed thoroughly with a mixture made of absolute ethanol and deionized water $\left(\mathrm{C}_{2} \mathrm{H}_{5} \mathrm{OH}\right.$; ZorkaPharma, Šabac, Serbia) to remove any melt residue and then dried. The morphology and the composition of the deposits were analysed using scanning electron microscope (TESCAN Digital Microscope; model VEGA 3, Brno, Czech Republic), equipped with an energy dispersive spectrometer (EDS Oxford INCA 3.2, High Wycombe, UK). The deposits collected from GC WE were also analysed by X-ray diffraction (XRD) measurements on Philips PW 1050 powder diffractometer (Philips, Delft, The Netherlands) at room temperature with Ni filtered $\mathrm{CuK} \alpha$ radiation $\left(\lambda=1.54178 \AA\right.$ ) , scintillation detector within $20-80^{\circ} 2 \theta$ range in steps of $0.05^{\circ}$, and scanning time of $5 \mathrm{~s}$ per step. Phases formed during deposition were identified by a comparison of the standard reference X-ray powder diffraction patterns for phase identification, Joint Committee on Powder Diffraction Standards (JCPDS) database. 


\section{Results and Discussion}

\subsection{Vanadium Dissolution and Deposition in Equimolar $\mathrm{AlCl}_{3}+\mathrm{NaCl} \mathrm{Melt}$}

To analyse the anodic and cathodic processes taking part on the vanadium electrode in equimolar $\mathrm{AlCl}_{3}+\mathrm{NaCl}$ melt, potentiodynamic polarization curve and cyclic voltammetry measurements were performed, Figures 1 and 2.

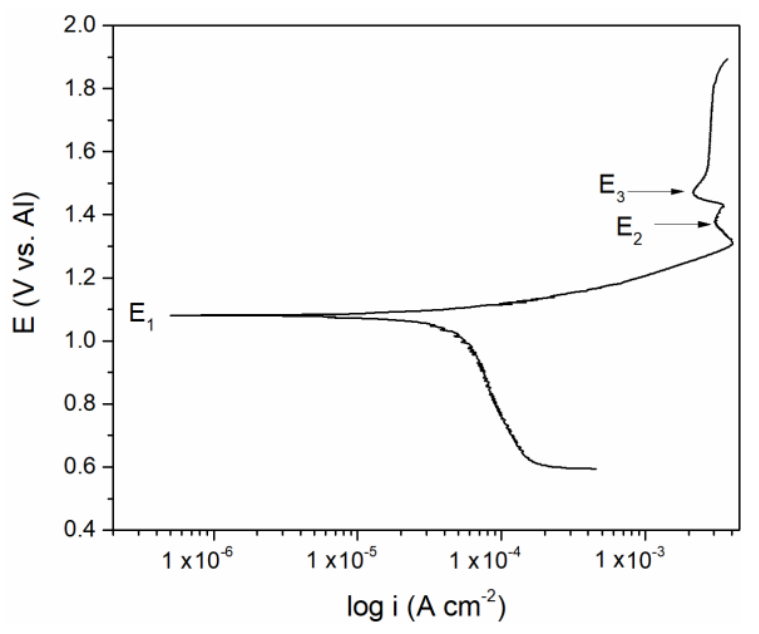

(a)

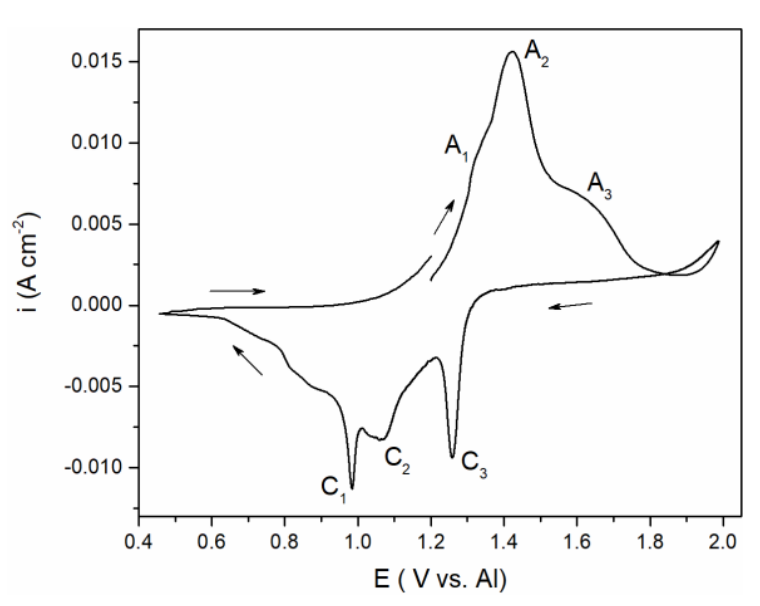

(b)

Figure 1. (a) Potentiodynamic polarization curve of vanadium working electrode (WE) in equimolar melt $\mathrm{AlCl}_{3}+\mathrm{NaCl}$, $\mathrm{T}=200{ }^{\circ} \mathrm{C}$, potential range: $\mathrm{E}_{\mathrm{I}}=0.600 \mathrm{~V} \rightarrow \mathrm{E}_{\mathrm{AF}}=1.900 \mathrm{~V}$ vs. $\mathrm{Al} ; v=1 \mathrm{mVs}^{-1} ;(\mathbf{b})$ Cyclic voltammogram of vanadium $\mathrm{WE}$ in equimolar $\mathrm{AlCl}_{3}+\mathrm{NaCl}$ melt, $\mathrm{T}=200{ }^{\circ} \mathrm{C}$, potential change from $\mathrm{E}_{\mathrm{I}}=1.200 \mathrm{~V}$ vs. Al to $\mathrm{E}_{\mathrm{AF}}=2.000 \mathrm{~V}$ vs. $\mathrm{Al}$, then to $\mathrm{E}_{\mathrm{CF}}=0.500 \mathrm{~V}$ vs. $\mathrm{Al}$ and finally back to $\mathrm{E}_{\mathrm{I}}=1.200 \mathrm{~V}$ vs. $\mathrm{Al}, v=20 \mathrm{mVs}^{-1}$.

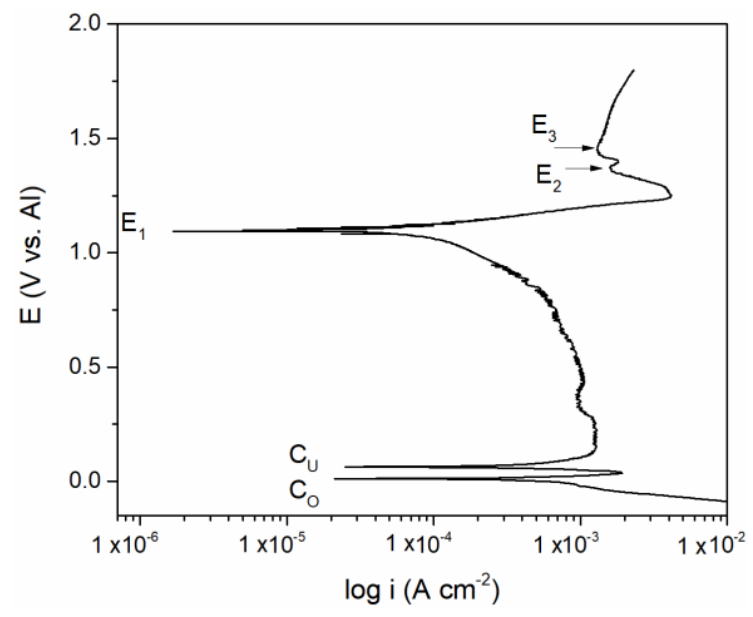

(a)

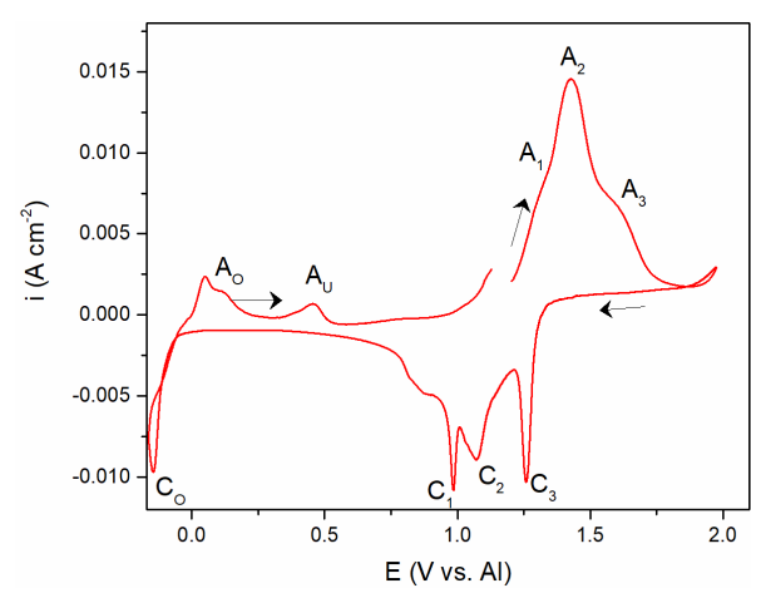

(b)

Figure 2. (a) Potentiodynamic polarization curve of $\mathrm{V}$ working electrode in equimolar melt $\mathrm{AlCl}_{3}+\mathrm{NaCl}, \mathrm{T}=200{ }^{\circ} \mathrm{C}$, potential range: $(\mathbf{a}) \mathrm{E}_{\mathrm{I}}=-0.100 \mathrm{~V} \rightarrow \mathrm{E}_{\mathrm{AF}}=1.900 \mathrm{~V}$ vs. $\mathrm{Al} v=1 \mathrm{mVs}^{-1}$; (b) voltammogram of vanadium WE in equimolar $\mathrm{AlCl}_{3}+\mathrm{NaCl}$ melt, $\mathrm{T}=200{ }^{\circ} \mathrm{C}$, potential change: from $\mathrm{E}_{\mathrm{I}}=1.200 \mathrm{~V}$ to $\mathrm{E}_{\mathrm{AF}}=2.000 \mathrm{~V} \mathrm{vs}$. $\mathrm{Al}$, then to cathodic end potentials of $\mathrm{E}_{\mathrm{CF}}=-0.150 \mathrm{~V}$ vs. $\mathrm{Al}$ and back to $\mathrm{E}_{\mathrm{I}}, v=20 \mathrm{mVs}^{-1}$.

Polarization curve in Figure 1a suggests a well-defined potential $\mathrm{E}_{1}$ at $1.100 \mathrm{~V}$ vs. $\mathrm{Al}$ and less pronounced potentials $\mathrm{E}_{2}$ at $\approx 1.350$ and $\mathrm{E}_{3}$ at $\approx 1.480 \mathrm{~V}$ vs. Al which correspond rather well with the "calculated equilibrium potentials" defined as a midpoint values between anodic and cathodic peak pairs $\left(\mathrm{A}_{1}+\mathrm{C}_{1}\right) / 2=1.150 \mathrm{~V},\left(\mathrm{~A}_{2}+\mathrm{C}_{2}\right) / 2=1.350 \mathrm{~V}$ and $\left(\mathrm{A}_{3}+\mathrm{C}_{3}\right) / 2=1.500 \mathrm{~V}$ vs. Al from Figure $1 \mathrm{~b}$. The recorded calculated and peak 
potentials were more than one volt anodic to the equilibrium potential of aluminium in the electrolyte used and therefore had to be attributed to the reversible reactions of the remaining constituents of the electrolyte. Chlorine evolution was found to start at potentials more positive than $2.000 \mathrm{~V}$ vs. Al and it is known that sodium equilibrium potential in chloride melts is substantially more negative than that of aluminium $[15,16]$. The recorded equilibrium and peak potentials, therefore, had to be attributed to vanadium species in metallic and ionized forms.

Vanadium ions were added to the equimolar electrolyte by dissolution of the vanadium working electrode. There are several studies on the vanadium ions being present in the chloride melts $\left(\mathrm{NaCl}+\mathrm{KCl}\right.$ at 690 to $\left.860^{\circ} \mathrm{C}\right)[15,16]$. The equilibrium potentials of the reactions: $\mathrm{V}(\mathrm{II}) \leftrightarrow \mathrm{V}(0), \mathrm{V}(\mathrm{III}) \leftrightarrow \mathrm{V}(\mathrm{II}), \mathrm{Cl}^{-}+2 \mathrm{e}^{-} \leftrightarrow \mathrm{Cl}_{2}$, were established [15,16]. In our study, the results suggested that in the presence of aluminium ions in equimolar chloroaluminate electrolyte $\left(0.19 \mathrm{~mol} \mathrm{AlCl}_{3}+0.19 \mathrm{~mol} \mathrm{NaCl}\right.$ at 200 to $\left.300{ }^{\circ} \mathrm{C}\right)$ vanadium behaved very similarly. This helped us to attribute the recorded potentials $\mathrm{E}_{1} \approx 1.100 \mathrm{~V}, \mathrm{E}_{2}$ $\approx 1.350 \mathrm{~V}$ and $\mathrm{E}_{3} \approx 1.480 \mathrm{~V}$ vs. Al in Figure 1 a to $\mathrm{V}(\mathrm{II}) \leftrightarrow \mathrm{V}(0), \mathrm{V}(\mathrm{III}) \leftrightarrow \mathrm{V}(\mathrm{II})$, and $\mathrm{V}(\mathrm{IV}) \leftrightarrow$ $\mathrm{V}$ (III) reactions, respectively. It was then possible to identify the processes reflected by the current waves in Figure $1 b$ : current wave $A_{1}$, should be related to the process of vanadium dissolution $\mathrm{V}(0) \rightarrow \mathrm{V}(\mathrm{II}) ; \mathrm{A}_{2}$ at more anodic potentials presents further oxidation reaction $\mathrm{V}(\mathrm{II}) \rightarrow \mathrm{V}(\mathrm{III})$; current wave $\mathrm{A}_{3}$, at even more positive potentials, reflects the oxidation process of $\mathrm{V}(\mathrm{III}) \rightarrow \mathrm{V}(\mathrm{IV})$, Figure $1 \mathrm{~b}$. In the reverse scan, $\mathrm{C}_{3}$ and $\mathrm{C}_{2}$ are reflecting the reduction processes of vanadium ions $\mathrm{V}(\mathrm{IV}) \rightarrow \mathrm{V}(\mathrm{III})$, and $\mathrm{V}(\mathrm{III}) \rightarrow \mathrm{V}(\mathrm{II})$, respectively. Current peak $\mathrm{C}_{1}$ reflects the reduction of $\mathrm{V}(\mathrm{II})$ ions to the metal vanadium and the deposition onto the vanadium working electrode.

The polarization curve and cyclic voltammograms recorded on the vanadium working electrode which included aluminium deposition and dissolution in addition to the vanadium dissolution and deposition are presented in Figure 2a,b. Polarization curve, Figure $2 \mathrm{a}$, starting from the potentials negative to aluminium equilibrium potential in the electrolyte used revealed two well-defined potentials, $\mathrm{C}_{\mathrm{O}}$ at $\approx 0.000 \mathrm{~V}$ and $\mathrm{C}_{\mathrm{U}}$ at $\approx 0.080 \mathrm{~V}$ vs. $\mathrm{Al}$, and a poorly defined one at $\mathrm{C}_{\mathrm{UP}} \approx 0.350 \mathrm{~V}$ vs. $\mathrm{Al}$, followed by the potentials $\mathrm{E}_{1}, \mathrm{E}_{2}$, and $E_{3}$. It was observed that the values of the three most positive potentials $\left(E_{1}, E_{2}\right.$, and $E_{3}$ ) are identical to those three recorded by polarization curve in Figure $1 \mathrm{a}$ and could be attributed to the same reactions of vanadium dissolution/deposition and vanadium ion oxidation/reduction.

$\mathrm{CV}$ measurements presented in Figure $2 \mathrm{~b}$, were done as follows:

- $\quad$ Starting potential was $1.200 \mathrm{~V}$ vs. Al, the potential more positive to the vanadium equilibrium potential in the equimolar $\mathrm{AlCl}_{3}+\mathrm{NaCl}$ electrolyte;

- $\quad$ Potential was then changed to $2.000 \mathrm{~V}$ vs. Al, which is close enough to the chlorine evolution potential;

- $\quad$ At $2.000 \mathrm{~V}$ vs. Al, the potential was then directed toward cathodic end value ( $\mathrm{E}_{\mathrm{CF}}$ $=-0.150 \mathrm{~V}$ vs. Al) which was cathodic to the Al equilibrium potential in the used electrolyte;

- $\quad$ Potential was then returned to the starting value (1.200 V vs. Al).

Tracing the path of the system response recorded on the voltammogram, we first see three anodic current peaks $\left(A_{1}, A_{2}\right.$, and $\left.A_{3}\right)$ and their three cathodic counterparts $\left(C_{1}, C_{2}\right.$, and $\left.C_{3}\right)$ in the region which is defined between 0.600 and $2.000 \mathrm{~V}$ vs. Al in the graph. The values of the peak potentials were very similar to those presented in Figure $1 \mathrm{~b}$ and attributed to the same processes of vanadium dissolution/deposition and oxidation/reduction of the vanadium ions.

The values of the peak potentials related to the current waves $\left(A_{1}, A_{2}, A_{3}\right.$, and $C_{1}$, $\mathrm{C}_{2}, \mathrm{C}_{3}$ ) and their peaks, Figure $2 \mathrm{~b}$, were in very good accordance with the values of the three most anodic calculated equilibrium potentials presented by the potentiodynamic polarization curve of the vanadium working electrode, Figure 2a. These data were also in agreement with the conclusions obtained by Polovov at al. describing vanadium dissolution in sodium-potassium chloride melts, at temperatures above $680{ }^{\circ} \mathrm{C}$ [16]. 
To investigate further the processes of vanadium dissolution/deposition and vanadium ion oxidation/reduction that are represented by $A_{1} / C_{1}$ and $A_{2} / C_{2}$ current waves in Figures 1 and 2, a series of CVs spanning their potential range with scan rates from $5 \mathrm{mVs}^{-1}$ to $100 \mathrm{mVs}^{-1}$ were performed, see Figure 3a. The relationships between the peak maximum current densities and the square root of the scan rate applied are presented in Figure $3 b, c$.

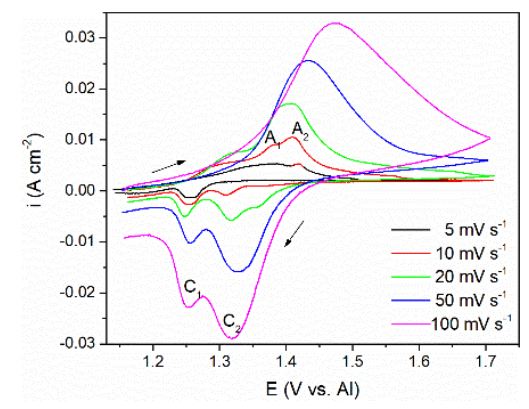

(a)

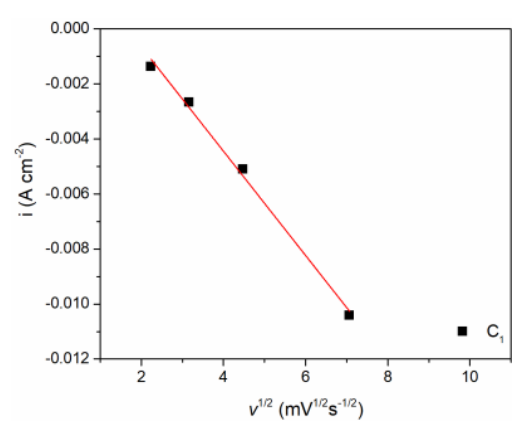

(b)

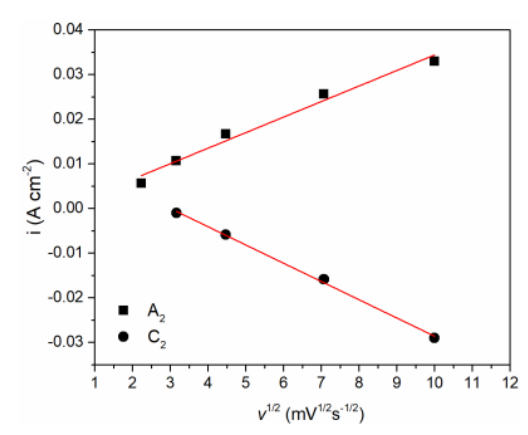

(c)

Figure 3. (a) Cyclic voltammograms of $\mathrm{V} \mathrm{WE}$ in equimolar $\mathrm{AlCl}_{3}+\mathrm{NaCl}$ melt, at $200{ }^{\circ} \mathrm{C}$, potential range: $\mathrm{E}_{\mathrm{I}}=1.100 \mathrm{~V}$ to $\mathrm{E}_{\mathrm{AF}}=1.700 \mathrm{~V}$ vs. $\mathrm{Al}$, recorded with different scan rates; (b) Plot of $\mathrm{C}_{1}$ peak current density vs. square root of the scan rates from Figure $3 a$; (c) Plots of $A_{2}$ and $C_{2}$ peak current density vs. square root of the scan rates from Figure $3 a$.

The CVs representing lower scan rates ( 5 and $10 \mathrm{mVs}^{-1}$ ) showed two distinct peak potentials $A_{1}$ and $A_{2}$ in the anodic section of the voltammograms. Peak $A_{1}$ was attributed to the dissolution process of vanadium metal: $\mathrm{V}(0) \rightarrow \mathrm{V}(\mathrm{II})$, and peak $\mathrm{A}_{2}$ reflects further oxidation of divalent vanadium (II) i.e., $\mathrm{V}$ (II) $\rightarrow \mathrm{V}$ (III). With increased scan rate, only one broader peak was observed, occupying the potential range of both $\mathrm{A}_{1}$ and $\mathrm{A}_{2}$. This behavior is typically a result of the next process (current wave $A_{2}$ ) starting at an increasing rate while the previous process (current wave $A_{1}$ ) rate is fading away [16]. Thus, the obtained one united current wave represents the sum of rates of both processes taking part in a partly shared potential span. Therefore, a proper analysis $i_{\text {peak }}=f\left(v^{1 / 2}\right)$ for $A_{1}$ could not be made. However, analysis of its cathodic counterpart, the deposition current wave $\mathrm{C}_{1}$, was possible and showed that the peak current vs. square root of the scan rate is linear and does not pass through the origin. This implies that the $\mathrm{V}$ (II) ion reduction process $\mathrm{V}$ (II) $\rightarrow \mathrm{V}(0)$ is under mixed control: by the diffusion rate of the complexed vanadium ions from the bulk of the molten equimolar $\mathrm{AlCl}_{3}+\mathrm{NaCl}$ electrolyte toward the $\mathrm{WE}$ and by the rate of the charge transfer step [23]. Some other authors also came to the conclusion that both anodic dissolution of vanadium and vanadium deposition in sodium-potassium chloride melts are under the same mixed control $[15,16,24]$.

With the scan rate increased, maximum current densities for both oxidation $\left(\mathrm{A}_{2}\right)$ and reduction peaks $\left(C_{2}\right)$, were higher, but their peak potentials barely changed implying the reversibility of the redox process $\mathrm{V}(\mathrm{III}) \leftrightarrow \mathrm{V}$ (II). Analysis of the relationship $\mathrm{i}_{\text {peak }}=\mathrm{f}\left(v^{1 / 2}\right)$ for both $A_{2}$ and $C_{2}$ presented in Figure $3 c$ revealed linear relationships suggesting that oxidation of $\mathrm{V}$ (II) ions into $\mathrm{V}$ (III) ions and the reverse reduction $\mathrm{V}$ (III) $\rightarrow \mathrm{V}$ (II) processes are under mixed mass transport and charge transfer control, as suggested earlier in the literature in somewhat different electrolytes [15,16,24].

These findings were used in defining the regime for vanadium metal dissolution as a supply of vanadium ions to the equimolar $\mathrm{AlCl}_{3}+\mathrm{NaCl}$ molten salt electrolyte. Taking into account the results obtained by $\mathrm{CV}$ on the vanadium WE in the equimolar electrolyte system (Figures 1-3), controlled anodic dissolution of vanadium was done by applying a constant potential of $1.300 \mathrm{~V}$ vs. $\mathrm{Al}$ at $200{ }^{\circ} \mathrm{C}$. The chosen potential was anodic to the vanadium OCP, Figure 4 , and anodic enough to sustain vanadium metal dissolution. However, analysis of the current density-time diagram in Figure 4a expressed as the $\mathrm{i}=\mathrm{f}\left(\mathrm{t}^{-1 / 2}\right)$ relationship appeared 
to be approximately linear, Figure $4 \mathrm{~b}$, thus identifying the dissolution as predominantly mass transfer controlled [23].

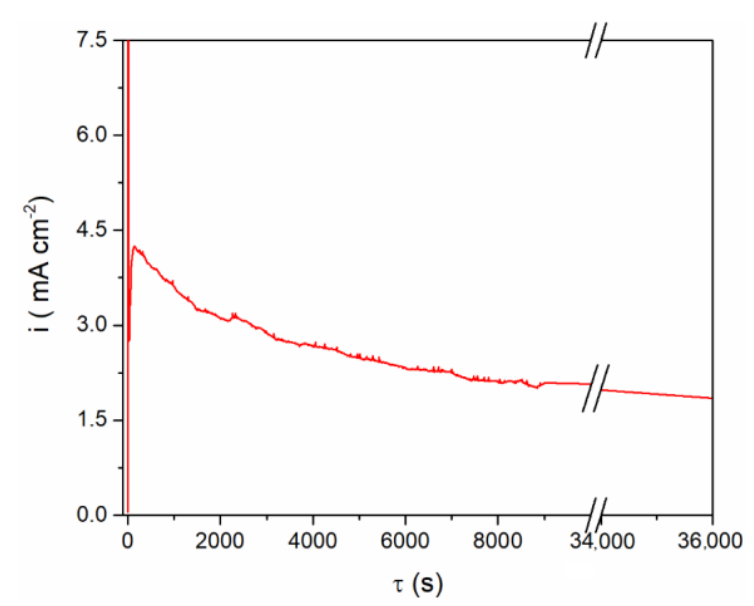

(a)

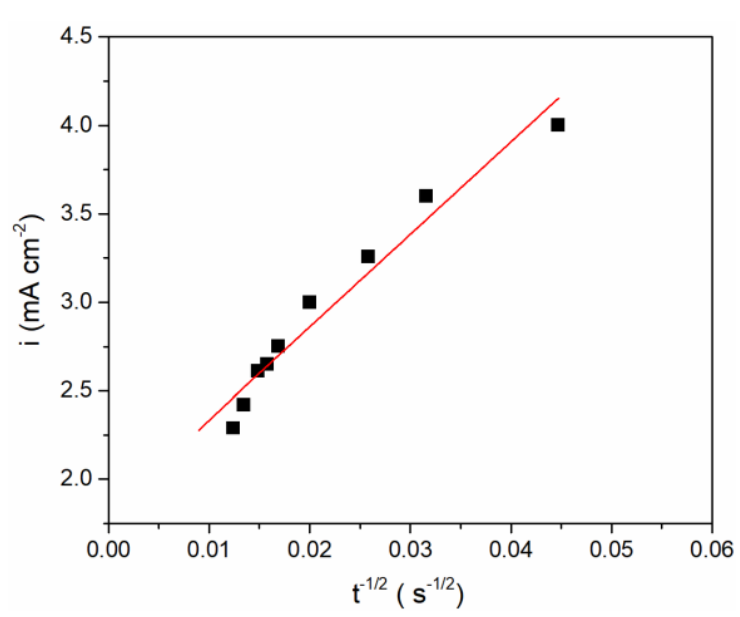

(b)

Figure 4. (a) Anodic dissolution of $\mathrm{V}$ working electrode at $1.300 \mathrm{~V}$ vs. Al for $10 \mathrm{~h}$ in equimolar melt $\mathrm{AlCl}_{3}+\mathrm{NaCl}_{\text {, }}$ $\mathrm{T}=200^{\circ} \mathrm{C} ;(\mathbf{b}) \mathrm{i}=\mathrm{f}\left(\mathrm{t}^{-1 / 2}\right)$ for the falling part of the transient obtained during vanadium dissolution process presented in $(\mathbf{a})$.

The final concentration of vanadium ions in the electrolyte obtained by anodic vanadium dissolution was determined in two ways: (1) from Faraday's Law, using the number of exchanged electrons as $n=2$ with respect to the oxidation process, $\mathrm{V}(0) \rightarrow \mathrm{V}$ (II), for example Figure 4a; and (2) from the vanadium working electrode mass lost during controlled potentiostatic dissolution. The results obtained by these two methods agreed well and showed that after controlled electro-dissolution the vanadium (II) ions concentration in the equimolar $\mathrm{AlCl}_{3}+\mathrm{NaCl}$ electrolyte was $\approx 5$ millimolar.

3.2. Vanadium and Aluminium Deposition from Equimolar $\mathrm{AlCl}_{3}+\mathrm{NaCl} \mathrm{Melt}$ Containing $V$ Ions Introduced Either by Anodic Dissolution of $V$ Metal or by Adding $\mathrm{VCl}_{3}$

A comparative study of the CV measurements was conducted with the GC working electrode in (a) the equimolar melt, which was 5 millimolar with respect to the vanadium ions introduced by vanadium anode dissolution, and (b) the equimolar melt, which was made to be 12.5 millimolar with respect to the vanadium ions by added $\mathrm{VCl}_{3}$. The WE potential was scanned from $\mathrm{E}_{\mathrm{I}}$ values positive to the vanadium equilibrium potential to $\mathrm{E}_{\mathrm{CF}}$ close to the aluminium equilibrium potential and back, enabling the recording of the ongoing electrochemical reactions related to the vanadium and aluminium in the chosen electrolytes, Figure 5a,b.

From the voltammogram obtained in the equimolar melt containing anodically dissolved $\mathrm{V}$ ions, the cathodic peak $\left(\mathrm{C}_{1}\right)$ at around $1.000 \mathrm{~V}$ vs. $\mathrm{Al}$ in the scanned potential region is reflecting $\mathrm{V}(\mathrm{II}) \rightarrow \mathrm{V}(0)$ ions reduction into vanadium metal, Figure $5 \mathrm{a}$, and the equilibrium potential of $\mathrm{V}(\mathrm{II}) \leftrightarrow \mathrm{V}(0)$ was noted at $\approx 1.100 \mathrm{~V}$ vs. Al. The structure of the anodic and cathodic peaks appearing in the potential range from $1.000 \mathrm{~V}$ to $2.000 \mathrm{~V} \mathrm{vs}$. Al in both systems on GC presented in Figure $5 a, b$ is not as detailed as on the V electrode (see Figures $1 b, 2 b$ and $3 a)$. Recent studies in chloride melts indicated that anodic dissolution of vanadium metal produces V(II) species, and the presence of vanadium metal in the electrolyte system suppresses the disproportion of V(II) [16,25]. According to the results obtained in our study, (Figure 5), it seems that vanadium ions added to the equimolar $\mathrm{AlCl}_{3}+\mathrm{NaCl}$ melt by controlled electrochemical dissolution behave in the same manner.

Current from the wave of vanadium deposition $C_{1}$ in Figure $5 a, b$, towards more negative potentials, diminishes but remains at the value which can be recognized as equal or close to the diffusion controlled, vanadium deposition limiting current. 


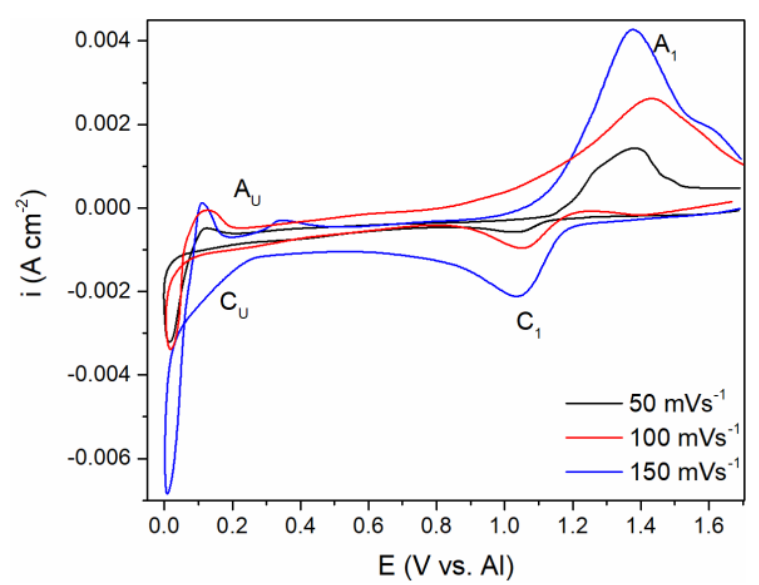

(a)

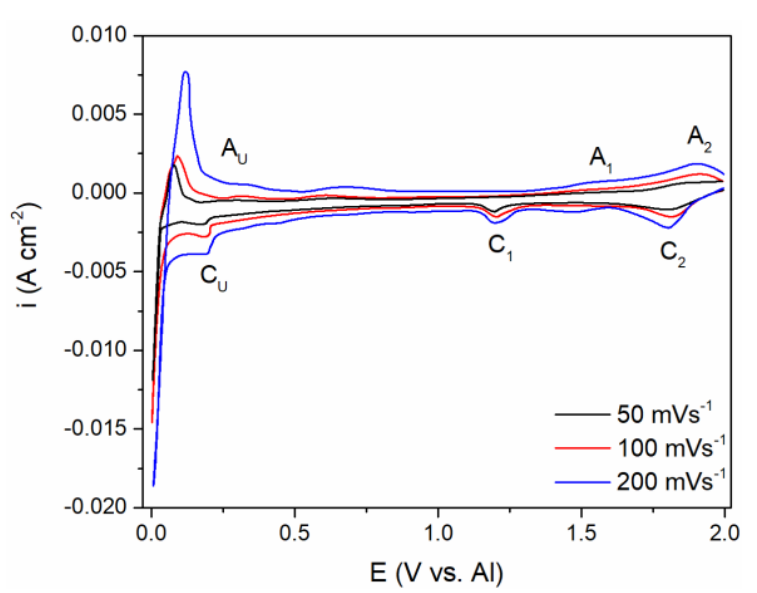

(b)

Figure 5. Cyclic voltammograms recorded on glassy carbon (GC) WE with different scan rates: (a) in equimolar $\mathrm{AlCl}_{3}+$ $\mathrm{NaCl}+$ anodically dissolved $\mathrm{V} ; \mathrm{T}=200{ }^{\circ} \mathrm{C} ;(\mathbf{b})$ in equimolar $\mathrm{AlCl}_{3}+\mathrm{NaCl}+$ vanadium(III)chloride, $\mathrm{T}=200{ }^{\circ} \mathrm{C}$.

At potentials from 0.200 to $0.300 \mathrm{~V}$ positive to the aluminium equilibrium potential, reduction current rises again into a visible wave $C_{U}$. Its value cannot possibly reflect just the vanadium diffusion limited deposition current any more but might reflect a sum of the underpotential deposition (UPD) of aluminium onto vanadium previously deposited on the original working electrode and the vanadium diffusion limited deposition current $[8,9]$.

The voltammograms recorded in the equimolar melt with $\mathrm{VCl}_{3}$ added, under all other conditions kept the same, presented a different number of reduction current peaks in the potential range from 2.000 to $1.000 \mathrm{~V}$ vs. Al, Figure $5 \mathrm{~b}$. Two distinct cathodic peak potentials were recognized:

- Peak $\mathrm{C}_{1}$ at $\approx 1.800 \mathrm{~V}$ vs. $\mathrm{Al}$, which should reflect the reduction process of $\mathrm{V}(\mathrm{III})+\mathrm{e}^{-}$ $\rightarrow \mathrm{V}(\mathrm{II})$

- $\quad$ Peak $\mathrm{C}_{2}$ at $\approx 1.180 \mathrm{~V}$ vs. $\mathrm{Al}$, which should depict the deposition process of $\mathrm{V}(\mathrm{II})+2 \mathrm{e}^{-}$ $\rightarrow \mathrm{V}(0)$.

The presence of the two reduction waves $\left(C_{1}\right.$ and $\left.C_{2}\right)$ within the potential range from 2.000 to $1.000 \mathrm{~V}$ vs. $\mathrm{Al}$ is in accordance with the previous findings that $\mathrm{VCl}_{3}$ dissolved in chloride melts yields V(III) ions [15].

The appearance of the reduction current wave $C_{U}$ at around $0.200-0.300 \mathrm{~V}$ vs. $\mathrm{Al}$ as a follow-up to the vanadium diffusion-controlled deposition current in Figure 5b, indicates aluminium underpotential deposition (UPD) onto metal vanadium covering the surface of the original WE. This was recognized in our previous works, and recorded as $\mathrm{C}_{\mathrm{UP}}$ in Figure 2a $[8,9]$. Further increase in the current density, within the $C_{U}$ current wave should be the result of summing up of the vanadium mass controlled deposition current and aluminium underpotential deposition current growing with increased negativity of the WE potential, Figure $5 \mathrm{a}, \mathrm{b}$. It should be noted that the diffusion-controlled vanadium deposition current in the potential range between $\approx 1.100 \mathrm{~V}$ to $\approx 0.250 \mathrm{~V} \mathrm{vs}$. Al, in the electrolyte made with $\mathrm{VCl}_{3}$ (Figure $5 \mathrm{~b}$ ), is 2-3 times higher than in the electrolyte with anodic dissolution obtained vanadium ions (Figure 5a). It is to be expected because the V(II) concentration in the first electrolyte was 2.5 to 3 times higher than in the latter.

The current waves, $A_{1}$ in Figure $5 a ; A_{1}$ and $A_{2}$ in Figure $5 b ; A_{1}, A_{2}, A_{3}$ in Figure $2 b$, are oxidation counterparts to the cathodic reactions $C_{1}, C_{2}$, and $C_{3}$. In all three electrolytes used, $A_{1}$, as a response to $C_{1}$, reflects vanadium dissolution while $A_{2}$ and $A_{3}$ reflect the oxidation part of the redox reaction between $\mathrm{V}(\mathrm{II}), \mathrm{V}(\mathrm{III})$, and $\mathrm{V}(\mathrm{IV})$ ions.

The second group of anodic current waves, a number of current waves marked as $A_{U}$ in Figure $5 a, b$ and $A_{O}$ and $A_{U}$ in Figure $2 b$, are responses to the cathodic current waves, $C_{U}$ in Figure $5 a, b$ and $C_{O}$ in Figure $2 b$, and can be ascribed to the partial stripping of 
the electrodeposited $\mathrm{Al}$ and $\mathrm{Al}-\mathrm{V}$ alloys, having naturally different dissolution potentials. This is more apparent in the case of the voltammogram in Figure $2 b$, where the peaks $A_{O}$ probably reflect the dissolution of overpotentially deposited aluminium and some of the Al$\mathrm{V}$ alloys formed concurrently and $\mathrm{A}_{\mathrm{U}}$, which should reflect the dissolution of the Al-V alloy made during $\mathrm{Al}$ UPD onto vanadium working electrode, Figure $2 \mathrm{~b}$, and on the vanadium previously deposited onto GC working electrode, Figure $5 \mathrm{a}, \mathrm{b}$. The potentials of those peaks $\left(\mathrm{A}_{\mathrm{O}}\right.$ and $\mathrm{A}_{\mathrm{U}}$ ) are close to the equilibrium potentials (recorded by potentiodynamic polarization curve in Figure 2a marked as $\mathrm{C}_{\mathrm{O}}$ at $0.000 \mathrm{~V}$ and $0.080 \mathrm{~V}$ and $\mathrm{C}_{\mathrm{U}} \approx 0.350 \mathrm{~V}$ vs. $\mathrm{Al}$, respectively.

To follow up on the aluminium and vanadium deposition/dissolution processes noticed with $\mathrm{CV}$ on GC electrode in the equimolar $\mathrm{AlCl}_{3}+\mathrm{NaCl}$ melt containing $\mathrm{V}$ ions added to the electrolyte either by vanadium anodic dissolution or by $\mathrm{VCl}_{3}$ addition, the voltammetry applying different holding times at chosen cathodic end potentials, $\mathrm{E}_{\mathrm{CF}}$, before returning to the starting potential was recorded, Figure $6 \mathrm{a}, \mathrm{b}$. In both cases, the cathodic end potential was held at $0.050 \mathrm{~V}$ vs. Al. In these sets of experiments, where the cathodic end potential $\mathrm{E}_{\mathrm{CF}}$ was not negative to the aluminium equilibrium potential, the anodic current waves reflecting the dissolution processes appeared at the potentials very similar to the values recorded on CVs presented in Figures $2 \mathrm{~b}$ and 5 . However, under the same experimental conditions, the cathodic and anodic peaks of the voltammograms recorded in the equimolar melt with $\mathrm{VCl}_{3}$ added, were more clearly defined $\left(\mathrm{A}_{\mathrm{U} 1}, \mathrm{~A}_{\mathrm{U} 2}\right.$, and $\left.\mathrm{A}_{\mathrm{U} 3}\right)$, and maxima of the anodic and cathodic peak currents were higher. Generally, the increased deposition time generated an increase in the maximum peak current and charge encompassed by the anodic current peaks. This suggests that with prolonged deposition time under the constant potential applied, quantity of vanadium and aluminium electrodeposited increases, and that $\mathrm{Al}-\mathrm{V}$ intermetallics are formed between vanadium and underpotentially deposited aluminium. Actually, aluminium is deposited by underpotential deposition on the vanadium that was previously deposited in the quantity which dominates the GC surface [8].

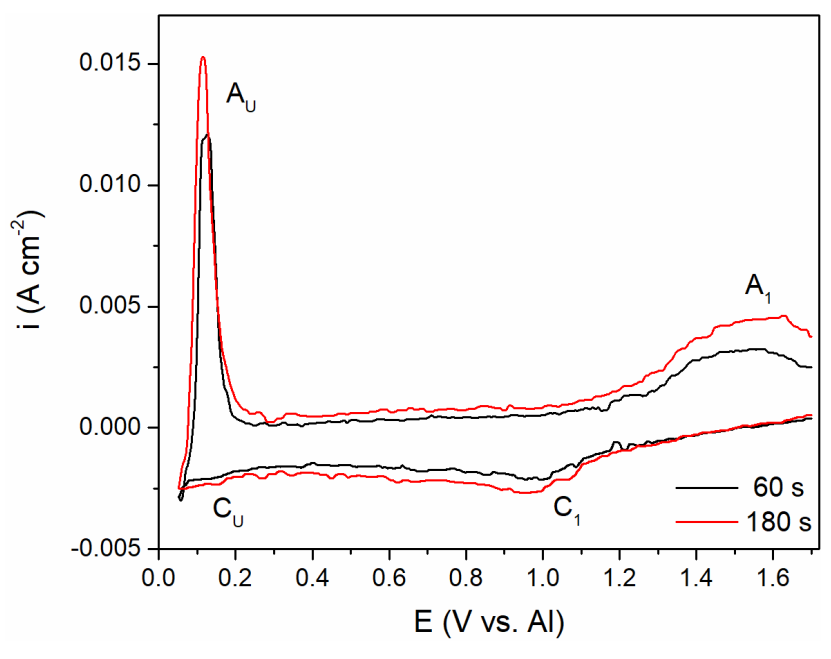

(a)

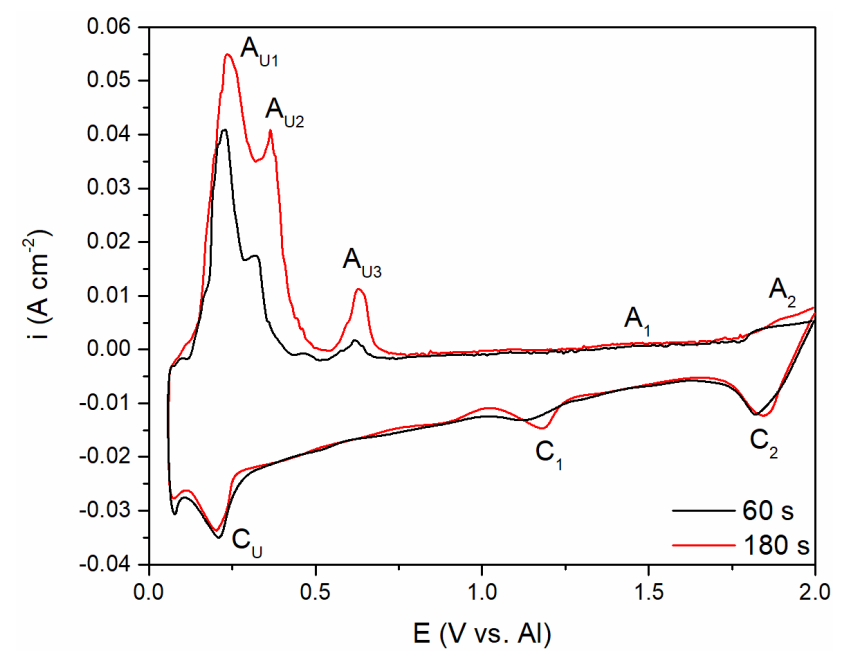

(b)

Figure 6. Hold on GC working electrode at potential $\mathrm{E}_{\mathrm{C}}=0.050 \mathrm{~V}$ vs. $\mathrm{Al} ; \mathrm{T}=200{ }^{\circ} \mathrm{C}, v=100 \mathrm{mVs}^{-1}$; in: (a) the equimolar melt containing anodically dissolved vanadium; $(\mathbf{b})$ the equimolar melt with vanadium added by $\mathrm{VCl}_{3}$.

Aluminium underpotential deposition with previously deposited vanadium enters into solid-state interdiffusion processes and first quantities of $\mathrm{Al}-\mathrm{V}$ intermetallics are synthetized. Prolonged vanadium deposition and aluminium underpotential deposition provide additional material for more alloy formation. Obviously, there was not only one 
intermetallic synthetized, because there were several anodic dissolution peaks $\left(A_{U 1}, A_{U 2}\right.$, $\left.\mathrm{A}_{\mathrm{U} 3}\right)$ reflecting different intermetallics having different dissolution potentials $[8,9]$.

\subsection{Characterization of Electrodeposited Al-V Intermetallic}

Surface morphologies of the Al-V alloys produced by potentiostatic aluminium underpotential and vanadium codeposition from equimolar $\mathrm{AlCl}_{3}+\mathrm{NaCl}$ melt containing anodically dissolved vanadium at $0.020 \mathrm{~V}$ vs. $\mathrm{Al}$, and from the equimolar $\mathrm{AlCl}_{3}+\mathrm{NaCl}$ melt with vanadium added as $\mathrm{VCl}_{3}$ at $0.050 \mathrm{~V}$ vs. $\mathrm{Al}$, are presented Figures 7 and 8 , respectively.

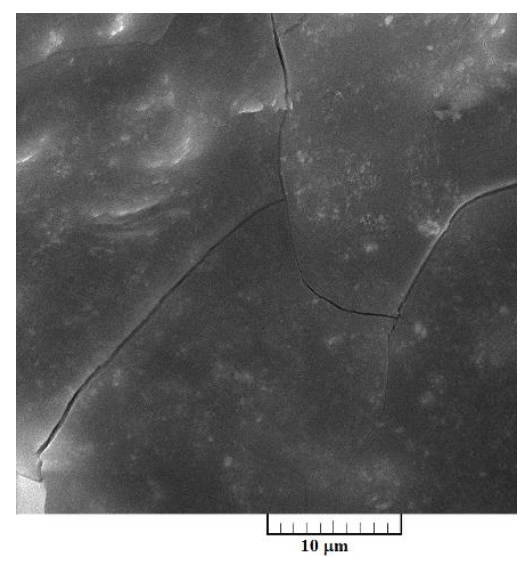

(a)

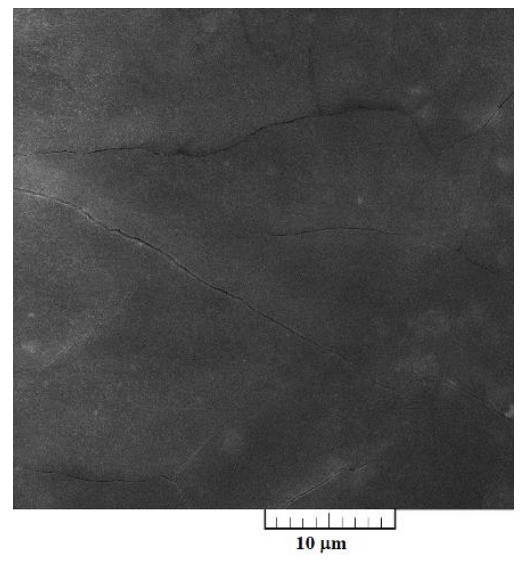

(b)

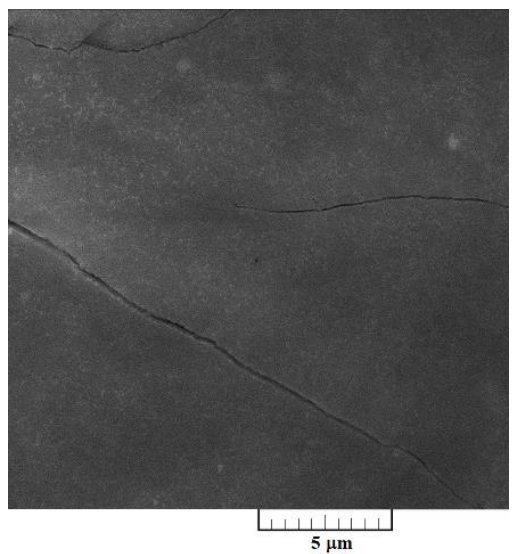

(c)

Figure 7. SEM micrographs of electrochemically produced $\mathrm{Al}-\mathrm{V}$ alloys from the equimolar $\mathrm{AlCl}_{3}+\mathrm{NaCl}$ melt containing anodically dissolved $\mathrm{V}$ at $0.020 \mathrm{~V}$ vs. Al, deposition time $5 \mathrm{~h}$, at $200^{\circ} \mathrm{C}$; at: $(\mathbf{a}, \mathbf{b})$ low magnification and (c) higher magnification.

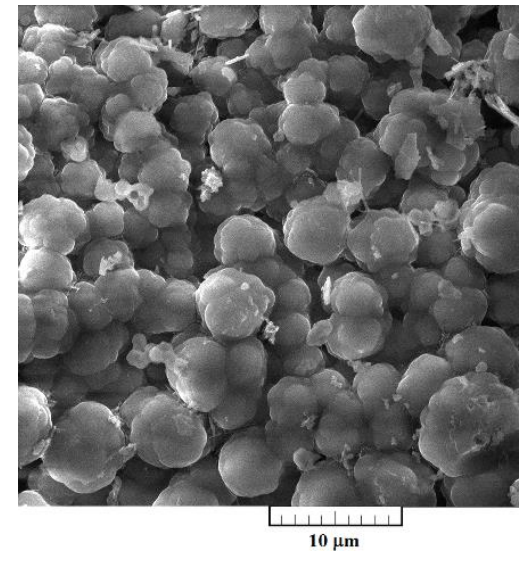

(a)

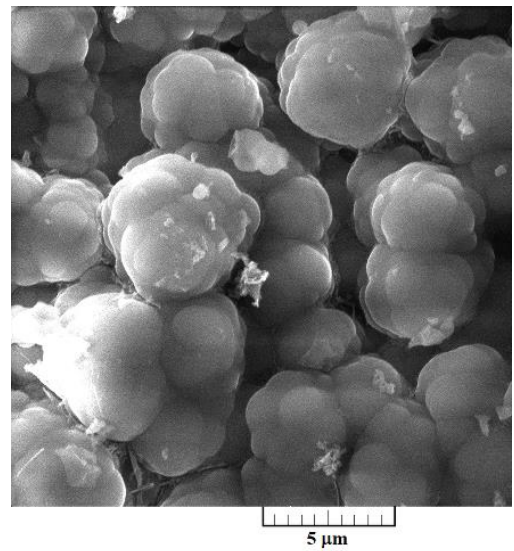

(b)

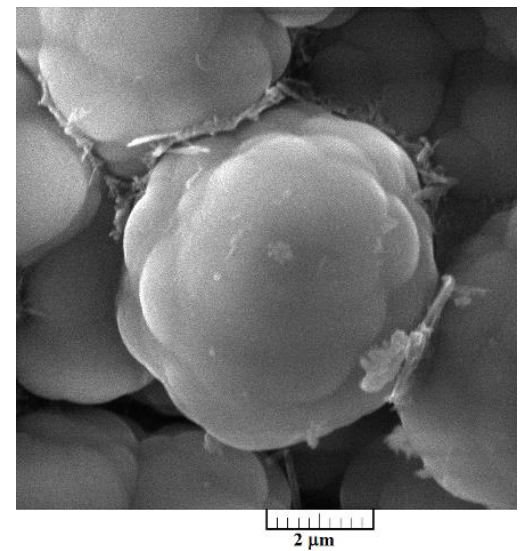

(c)

Figure 8. SEM micrographs of electrochemically produced $\mathrm{Al}-\mathrm{V}$ alloys from the equimolar $\mathrm{AlCl}_{3}+\mathrm{NaCl}_{\text {with vanadium }}$ added by $\mathrm{VCl}_{3}$ at $0.050 \mathrm{~V}$ vs. $\mathrm{Al}$, deposition time $5 \mathrm{~h}$, at $200{ }^{\circ} \mathrm{C}$; at: (a,b) low magnification, and (c) higher magnification.

Presence of the aluminium and vanadium in the deposits were reported by EDS semiquantitative analysis in the samples presented in Figures 7 and 8 . The deposit produced by potentiostatic electrodeposition from electrolyte containing anodically dissolved vanadium, besides oxygen, which was impossible to avoid during sample handling, has shown the content of aluminium at 38.55 at. \% and vanadium of 23.15 at. \%. Content of aluminium was 66.29 at. \% and of vanadium 29.18 at. \% in the sample obtained by electrodeposition from the electrolyte with vanadium added by $\mathrm{VCl}_{3}$. According to the EDS analysis, the deposits were free from chloride contamination. EDS data presented were collected from the entire surface given in Figures 7a and 8a. 
SEM photographs in Figure 7a-c represent a deposit obtained on GC electrode by potentiostatic aluminium underpotential deposition at $0.020 \mathrm{~V}$ vs. Al from the electrolyte containing anodically dissolved vanadium. The micrographs expose a relatively smooth and compact surface coating, well adhered to the working substrate. However, a deposit obtained on GC electrode by the deposition from the electrolyte with vanadium added by $\mathrm{VCl}_{3}$ at $0.050 \mathrm{~V}$ vs. Al, exhibited almost uniformly distributed 3D forms of the cauliflowerlike structures, Figure 8a-c. Individual forms seem to be constructed from approximately spherical grains as the basic element, Figure 8c. From Figure 8a-c, it appears that they have been closely packed, with the average particles size around $5 \mu \mathrm{m}$, and completely covered the GC surface area.

In order to identify the intermetallics synthetized during simultaneous vanadium deposition and aluminium underpotential deposition, $\mathrm{XRD}$ analysis of the deposit obtained on the GC working electrode at the potential of $0.020 \mathrm{~V}$ vs. Al applied for $5 \mathrm{~h}$ in the electrolyte containing anodically dissolved $\mathrm{V}$ was conducted. The analysis identified $\mathrm{Al}_{3} \mathrm{~V}$ and $\mathrm{AlV}_{3}$ as present in the sample, Figure 9a. Peaks identified in the diffractogram at $2 \theta=25.87^{\circ}, 33.50^{\circ}, 40.07^{\circ}, 48.11^{\circ}, 66.83^{\circ}, 70.41^{\circ}$, and $77.47^{\circ}$ can be indexed to (101), (110), (112), (200), (204), (220), and (116) reflections from body-centered tetragonal $\mathrm{Al}_{3} \mathrm{~V}$ [JCPDS No. 03-065-2664]. The diffraction peaks at $2 \theta=41.73^{\circ}, 60.50^{\circ}, 76.19^{\circ}$ are indexed to (110), (200) and (211) reflections from body-centered cubic $\mathrm{AlV}_{3}$ [JCPDS No. 03-065-5142].

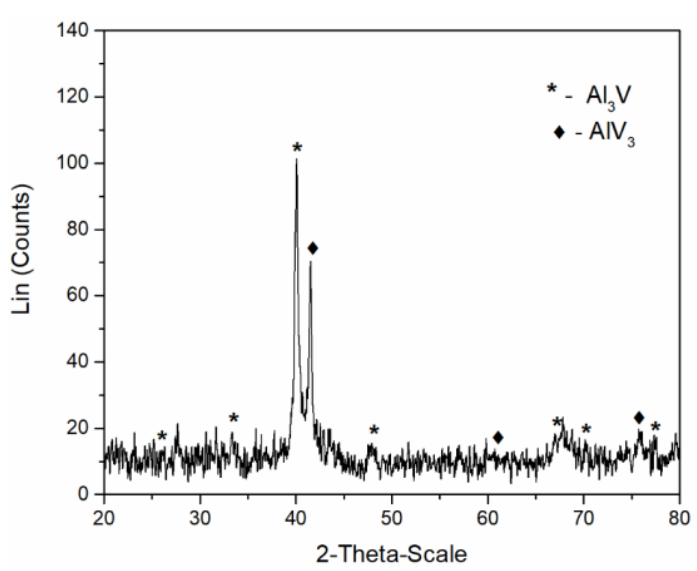

(a)

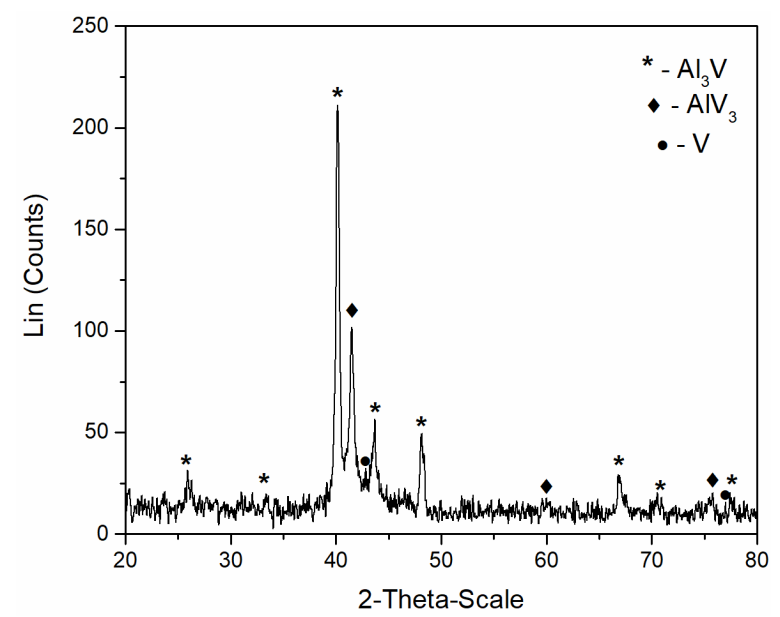

(b)

Figure 9. XRD patterns of electrochemically produced deposit on GC working electrode at $200{ }^{\circ} \mathrm{C}$; deposition time $5 \mathrm{~h}$ : (a) from the equimolar $\mathrm{AlCl}_{3}+\mathrm{NaCl}$ melt containing anodically dissolved $\mathrm{V}$ at $0.020 \mathrm{~V}$ vs. $\mathrm{Al}$; (b) from the equimolar $\mathrm{AlCl}_{3}$ $+\mathrm{NaCl}$ with vanadium added by $\mathrm{VCl}_{3}$ at $0.050 \mathrm{~V}$ vs. $\mathrm{Al}$.

Very similar to these results were the XRD recordings of the deposit obtained on the GC working electrode at constant potential of $0.050 \mathrm{~V}$ vs. Al for $5 \mathrm{~h}$, in the electrolyte where as a source of $\mathrm{V}$ ions, $\mathrm{VCl}_{3}$ was used, Figure $9 \mathrm{~b}$. Apart from the prominent peaks corresponding to $\mathrm{Al}_{3}$ Vand $\mathrm{AlV}_{3}$ alloys, the XRD data indicated the traces of metallic $\mathrm{V}$ ( $2 \theta$ peaks at $42.28^{\circ}$ and $77.20^{\circ}$ [JCPDS No. 01-089-3059]) in the deposit.

Although the Al-V intermetallics are well characterized, the Al-V binary phase diagram still contains many uncertainties $[7,8,12]$. On the basis of binary Al-V phase diagram, four intermetallics can be identified among Al-rich alloys: $\mathrm{Al}_{21} \mathrm{~V}_{2}, \mathrm{A1}_{45} \mathrm{~V}_{7}, \mathrm{A1}_{23} \mathrm{~V}_{4}$, and $\mathrm{Al}_{3} \mathrm{~V}$, none of which can be formed at the temperatures below $600{ }^{\circ} \mathrm{C} . \mathrm{Al}_{3} \mathrm{~V}$, an aluminium rich compound, should occur in Al-V alloys containing 1-25 wt.\% V with $\mathrm{D}_{22}$ structure prepared at temperature above $746{ }^{\circ} \mathrm{C}$ [12].

Literature reports on metallographic and microprobe analyses made on dilute alloys heat treatment for short times at temperatures between $500{ }^{\circ} \mathrm{C}$ and $740{ }^{\circ} \mathrm{C}$, determined that $\mathrm{Al}_{3} \mathrm{~V}$ phase is an equilibrium phase with a tetragonal structure. Recently, it was reported 
that the alloy $\mathrm{Al}_{3} \mathrm{~V}$ was synthesized at temperatures from $1000{ }^{\circ} \mathrm{C}$ to $1400{ }^{\circ} \mathrm{C}$ from $\mathrm{Al}$ and relatively high vanadium content of 3-4wt.\% [13,26]. At temperature from $1000{ }^{\circ} \mathrm{C}$ to $1100{ }^{\circ} \mathrm{C}$ and all the way up to $1400{ }^{\circ} \mathrm{C}$ the amount of $\mathrm{Al}_{3} \mathrm{~V}$ increased.

As stated in a recent study [13], vanadium content in the melt was an important factor influencing the microstructure and controlling the types of V-containing phases formed in $\mathrm{Al}-\mathrm{V}$ alloys during rapid solidification process. $\mathrm{Al}_{3} \mathrm{~V}$ alloy was not formed until vanadium content reached at least $3 \mathrm{wt} . \%$ in the $\mathrm{Al}-\mathrm{V}$ alloy [13,27]. The dendritic $\mathrm{Al}_{3} \mathrm{~V}$ alloy was formed at higher vanadium content in the system, with the boundaries of the $\mathrm{Al}_{3} \mathrm{~V}$ phase spherical in shape.

In other words, alloys $\mathrm{Al}_{3} \mathrm{~V}$ and $\mathrm{AlV}_{3}$ recorded in the analysis made on the deposit formed by the electrodeposition of vanadium and aluminium from the equimolar $\mathrm{AlCl}_{3}+\mathrm{NaCl}$ melt containing vanadium ions onto $\mathrm{GC}$, at applied temperature $\left(20{ }^{\circ} \mathrm{C}\right)$ should not have been synthesized. However, it appears that in this case, potentiostatic electrodeposition is responsible for the controllable synthesis of the alloys. In our study, the deposits produced under all conditions being the same except the vanadium ion concentration in the electrolyte were identified as $\mathrm{Al}_{3} \mathrm{~V}$ and $\mathrm{AlV}_{3}$. It appears that the vanadium concentrations in the electrolyte used were adequate for $\mathrm{Al}_{3} \mathrm{~V}$ and $\mathrm{AlV}_{3}$ alloy formation. However, from the melt containing higher vanadium concentration in the electrolytes used, the deposit displayed a dendritic structure.

Our experiments have confirmed Al-V alloy generation by controlled aluminium and vanadium codeposition in the aluminium underpotential as well as overpotential region of the working potentials. The $\mathrm{Al}$ and $\mathrm{V}$ codeposition in the region of aluminium overpotentials will be a subject of another report. Nevertheless, it should be noted that the limiting factor in the $\mathrm{Al}$ and $\mathrm{V}$ codeposition in both aluminium overpotential and aluminium underpotential regions, is the vanadium ion concentration in the electrolyte used. The vanadium ion concentration in the electrolyte used dictates the largest vanadium deposition rate i.e., the mass transfer-controlled vanadium deposition current density. In the same time the vanadium dissolution in the chloride molten salts media is restricted to rather small values $[15,16,25,28]$.

\section{Conclusions}

$\mathrm{Al}_{3} \mathrm{~V}$ and $\mathrm{AlV}_{3}$ intermetallics have been successfully deposited by electrochemical aluminium and vanadium deposition onto glassy carbon electrode at $200{ }^{\circ} \mathrm{C}$ from the equimolar $\mathrm{AlCl}_{3}+\mathrm{NaCl}$ electrolyte with vanadium ions added. The alloys were synthetized during aluminium underpotential deposition onto vanadium metal that was previously deposited on the glassy carbon electrode by diffusion-controlled overpotential deposition. Alloys were the result of solid-state interdiffusion between the initially deposited vanadium and the subsequently deposited aluminium. Although, the electrolyte system with V(III) ions (the result of $\mathrm{VCl}_{3}$ dissolution) is being favored because of the easiness in handling than the melt containing V(II) ion (the result of anodic V dissolution) a compact and adhering deposit was obtained on GC electrode from both electrolytes used.

Findings made in this study seem to be a good basis for an innovative research toward controllable electrochemical synthesis of a vanadium trialuminide $\left(\mathrm{Al}_{3} \mathrm{~V}\right)$ and $\mathrm{A} 15$ alloy $\left(\mathrm{AlV}_{3}\right)$ intermetallics.

Author Contributions: V.S.C. designed, managed the research and writing-original draft preparation; N.M.V. performed most of the experiments and participated in the manuscript preparation; D.F. and K.M.-N. performed some of the experiments; T.S.B. XRD data curation; B.F. and J.N.J. helped with the corrections of the manuscript and supervised; B.F. from RWTH Aachen University provided funding for publication. All authors discussed the results and commented on the manuscript. All authors have read and agreed to the published version of the manuscript.

Funding: Part of the research was supported by the funds of the bilateral research project (ID: 451-0301971/2018-09/4) supported by the Ministry of Education, Science and Technological Development of the Republic of Serbia and German Academic Exchange Service (DAAD). 
Institutional Review Board Statement: Not applicable.

Informed Consent Statement: Not applicable.

Data Availability Statement: Not applicable.

Acknowledgments: Vesna S. Cvetković and Nataša M. Vukićević acknowledge the financial support for the investigation received from the Ministry of Education, Science, and Technological Development of the Republic of Serbia (Grant No. 451-03-68/2020-14/200026).

Conflicts of Interest: The authors declare no conflict of interest.

\section{References}

1. Xu, Y.; Jiao, H.; Wang, M.; Jiao, S. Direct preparation of $\mathrm{V}-\mathrm{Al}$ alloy by molten salt electrolysis of soluble $\mathrm{NaVO}_{3}$ on a liquid $\mathrm{Al}$ cathode. J. Alloys Compd. 2019, 779, 22-29. [CrossRef]

2. Wan, H.; Xu, B.; Li, L.; Yang, B.; Li, D.; Dai, Y. A Novel Method of Fabricating Al-V Intermetallic Alloy through Electrode Heating. Metals 2019, 9, 558. [CrossRef]

3. Yazdian, N.; Karimzadeh, F.; Enayati, M.H. In-situ fabrication of $\mathrm{Al}_{3} \mathrm{~V} / \mathrm{Al}_{2} \mathrm{O}_{3}$ nanocomposite through mechanochemical synthesis and evaluation of its mechanism. Adv. Powder Technol. 2013, 24, 106-112. [CrossRef]

4. Cvetkovic, V.; Jovicevic, N.; Vukicevic, N.; Jovicevic, J. Aluminium/zirconium alloys obtained by Al underpotential deposition onto $\mathrm{Zr}$ from low temperature $\mathrm{AlCl}_{3}+\mathrm{NaCl}$ molten salts. J. Serbian Chem. Soc. 2019, 84, 1329-1344. [CrossRef]

5. Sircar, S.; Chattopadhyay, K.; Mazumder, J. Nonequilibrium synthesis of $\mathrm{NbAl}_{3}$ and Nb-Al-V. Metall. Trans. A 1992, 23, $2419-2429$. [CrossRef]

6. Anvari, S.Z.; Karimzadeh, F.; Enayati, M.H. Synthesis and characterisation of nanostructured $\mathrm{Al}_{-}-\mathrm{Al}_{3} \mathrm{~V}$ and $\mathrm{Al}-\left(\mathrm{Al}_{3} \mathrm{~V}-\mathrm{Al}_{2} \mathrm{O}_{3}\right)$ composites by powder metallurgy. Mater. Sci. Technol. 2018, 34, 179-190. [CrossRef]

7. Okamoto, H. Al-V (Aluminum-Vanadium). J. Phase Equilibria Diffus. 2012, 33, 491. [CrossRef]

8. Jovićević, N.; Cvetković, V.S.; Kamberović, Ž.; Barudžija, T.S. Aluminium underpotential deposition from $\mathrm{AlCl}_{3}+\mathrm{NaCl}_{\mathrm{melts}}$ and alloy formation with vanadium substrate. Int. J. Electrochem. Sci. 2015, 10, 8959-8972.

9. Cvetković, V.S.; Vukićević, N.M.; Jovićević, J.N. Aluminium and Magnesium Alloy Synthesis by Means of Underpotential Deposition from Low Temperature Melts. In Metals and Metal-Based Electrocatalytic Materials for Alternative Energy Sources and Electronics; Stevanović, J., Ed.; Nova Science Publisher: New York, NY, USA, 2019; pp. 371-423. ISBN 6312317269.

10. Gussone, J.; Vijay, C.R.Y.; Haubrich, J.; Milicevic, K.; Friedrich, B. Effect of vanadium ion valence state on the deposition behaviour in molten salt electrolysis. J. Appl. Electrochem. 2018, 48, 427-434. [CrossRef]

11. Léger, J.M.; Hall, H.T. Pressure and temperature formation of $\mathrm{A}_{3} \mathrm{~B}$ compounds $\mathrm{I}_{\mathrm{N}} \mathrm{Nb}_{3} \mathrm{Si}$ and $\mathrm{V}_{3} \mathrm{Al}$. J. Less-Common Met. 1973, 32, 181-187. [CrossRef]

12. Murray, J.L. Al-V (aluminum-vanadium). Bull. Alloy. Phase Diagr. 1989, 10, 351-357. [CrossRef]

13. Meng, Y.; Cui, J.; Zhao, Z.; Zuo, Y. Study on Microstructures of Al-4 wt pct V Master Alloys. Metall. Mater. Trans. A 2014, 45, 3741-3747. [CrossRef]

14. Zhu, Q.; Meng, Y.; Kang, Y.; Kong, S.; Ou, Y.; Zuo, Y. Effect of cooling rate on morphology and type of vanadium-containing phases in Al-10V master alloy. China Foundry 2019, 16, 300-306. [CrossRef]

15. Polovov, I.B.; Chernyshov, M.V.; Volkovich, V.A.; Vasin, B.D.; Griffiths, T.R. Vanadium Speciation in Fused Alkali Chlorides. J. Electrochem. Soc. 2017, 164, H5139-H5144. [CrossRef]

16. Polovov, I.B.; Tray, M.E.; Chernyshov, M.V.; Volkovich, V.A.; Vasin, B.D.; Rebrin, O.I. Electrode Processes in VanadiumContaining Chloride Melts. In Molten Salts Chemistry and Technology; John Wiley \& Sons, Ltd: Chichester, UK, 2014; pp. 257-281, ISBN 9781118448847.

17. Milicevic, K.; Friedrich, B.; Gussone, J.; Haubrich, J. Anodic dissolution of vanadium in molten $\mathrm{LiCl}-\mathrm{KCl}-\mathrm{TiCl} 2$. J. Appl. Electrochem. 2017, 47, 573-581. [CrossRef]

18. Rebrin, O.I.; Scherbakov, R.Y.; Polovov, I.B.; Mihalev, S.M.; Volkovich, V.A.; Muhamadeev, A.S.; Vasin, B.D. Investigation of the Kinetics of Electrode Processes in Halide Melts Containing Beryllium, Vanadium, Niobium and Hafnium. ECS Proc. Vol. 2002, 19, 460-472. [CrossRef]

19. Verdieck, R.G.; Yntema, L.F. The Electrochemistry of Baths of Fused Aluminum Halides. IV. J. Phys. Chem. 1944, 48, 268-279. [CrossRef]

20. Tsuda, T.; Hussey, C.L. Electrochemistry of vanadium(II) and the electrodeposition of aluminum-vanadium alloys in the aluminum chloride-1-ethyl-3-methylimidazolium chloride molten salt. J. Min. Metall. Sect. B Metall. 2003, 39, 3-22. [CrossRef]

21. Vukićević, N.M.; Cvetković, V.S.; Jovanović, L.; Stevanović, S.I.; Jovićević, J.N. Alloy Formation by Electrodeposition of Niobium and Aluminium on Gold from Chloroaluminate Melts. Int. J. Electrochem. Sci. 2017, 12, 1075-1093. [CrossRef]

22. Radović, B.S.; Cvetković, V.S.; Edwards, R.A.H.; Jovićević, J.N. Al-Cu alloy formation by aluminium underpotential deposition from $\mathrm{AlCl}_{3}+\mathrm{NaCl}$ melts on copper substrate. Kov. Mater. 2010, 48, 159-171.

23. Greef, R.; Peat, R.; Peter, L.M.; Pletcher, D.; Robinson, J. Instrumental Methods in Electrochemistry, 1st ed.; Kemp, T.J., Ed.; Ellis Horwood Limited: Chichester, UK, 1985; ISBN 0-85312-875-8. 
24. Polovov, I.B.; Chernyshov, M.V.; Volkovich, V.A.; Rebrin, O.I.; Rylov, A.N. Vanadium Electrorefining in $\mathrm{NaCl}-\mathrm{KCl}-\mathrm{VCl} 2 \mathrm{Melts}$ ECS Trans. 2018, 86, 37-43. [CrossRef]

25. Chernyshov, M.V.; Polovov, I.B.; Rebrin, O.I.; Volkovich, V.A.; Kamalov, R.V.; Griffiths, T.R. Processing of Vanadium and Niobium Electrodeposited from Alkali Chloride Melts. ECS Trans. 2010, 33, 297-302. [CrossRef]

26. Grushko, B.; Velikanova, T.Y. Stable and metastable quasicrystals in Al-based alloy systems with transition metals. J. Alloys Compd. 2004, 367, 58-63. [CrossRef]

27. Lei, K.P.V.; Sullivan, T.A. High-purity vanadium. J. Less Common Met. 1968, 14, 145-147. [CrossRef]

28. Polovov, I.B.; Vasin, B.D.D.; Abakumov, A.V.V.; Rebrin, O.I.I.; Chernyshov, M.V.V.; Volkovich, V.A.; Griffiths, T.R.R. Thermodynamics of the Formation of Vanadium(II) Complexes in Chloride Melts. ECS Trans. 2019, 3, 589-597. [CrossRef] 